Journal of Social and Development Sciences

Vol. 1, No. 2, pp. 79-90, Mar 2011

\title{
Evolution of the MSMEs in India
}

\author{
Madhavi A Lokhande \\ Welingkar Education, 102 \& 103, Electronic City Phase 1, Hosur Road, Bangalore, India \\ madhavial@yahoo.com
}

\begin{abstract}
There is a growing and worldwide appreciation that the Micro, Small and Medium Enterprises play a catalytic role in the development process of most economies. This position gets reflected in the form of their increasing number and rising proportion in the overall product manufacturing, exports, manpower employment, technical innovations and promotion of entrepreneurial skills. This paper attempts to look at the changing definition of the Micro, Small and Medium Enterprises and the role these enterprises are playing in the growth story of our economy. In India, the MSME sector is the second largest manpower employer, after agriculture and the output from this sector alone constitutes 40 percent share of the value added in the manufacturing sector and one third of national exports. The importance of Micro, Small and Medium enterprises (MSME) for its contribution in the Indian economy growth is a matter of record and needs no further elaboration. However, with the changing focus from economic growth to inclusive growth, MSME sector's role in the socio economic development of India needs to be understood, explored and facilitated. The opportunity in MSMEs exists, however, the fact remains that most of the funding goes to the larger and more solvent MSMEs and to those who have business linkages with large corporate. The banks compete with each other to grant loans to the top rung MSMEs.
\end{abstract}

Key Words: Economic Development of India, Micro, Small and Medium Enterprises, Funding needs of MSMEs, Future of MSMEs, Unorganized sector.

\section{Introduction}

Economic Growth and Transformation in India: The Indian Economy has shown a remarkable performance of economic growth in the 90s. The growth rate of real Gross Domestic Product (GDP) passed a peak of $9.7 \%$ in 2007. Experts predict that India's GDP will grow annually at 7\%. The era of social and economic transformation is one of the leading chapters in the story of economic growth of the country. India is changing from an agrarian rural and agricultural society into a society with an economy dominated by the services and Industry sectors. Experience around the world suggests that the transformation process is resulting in a steep urbanization trend i.e., more people are migrating to cities and towns, from the villages and the rural areas. Compared to this trend India has actually recorded a slower urbanization rate over the last decade. About 1 out of 3 Indians live in towns, with the lion's share taken up by mega cities (more than 1 crore population) (GOI Report). On the one hand, there are potential threats arising due to the massive growth of slums followed by unemployment, inequalities, degradation in the quality of urban life leading to conflicts. On the other hand, the village is unable to give its people jobs. Nor it is possible to reform agriculture which will mean mechanization of farming resulting in fewer jobs. So it is not possible to modernize the Indian economy unless the country urbanize more rapidly and in a better manner than it has done so far. One slow down factor of Indian urbanization no doubt is the insecurity of urban poor's jobs which restrict them from bringing their families from the villages to the cities. As these jobs are often available only on a day to day basis, the job holders are never sure if they will have work and income the next day.

Ruchismita and Gupta (2005) in the approach paper on "Delivery of Comprehensive Financial Services to the Informal and Unorganized Sector" pointed out that a third of India's population continues to live in conditions of abject poverty. Most of these people are either unemployed or are engaged in vocations that are insufficient to even meet their basic physiological needs. Studies suggest that the largest number of this surplus labour will be absorbed by the tiny and very small scale enterprises, giving a big boost to the overall economy. These enterprises are diverse, in their size, employment opportunities, production of goods \& services, and are spread out throughout the geography of the nation. These small enterprises are identified to 
be part of the informal, unorganized, or the "Residual Sector". The report of Planning Commission of India substantiates this by stating that the GDP will grow at rates upward of 8 per cent which will be sustained mainly through the unorganized sector (Government of India, 2002). Although the organized sector is clearly identifiable, it cannot be said of the informal and the unorganized sector. The informal sector has been defined to include all enterprises that are not registered under any specific regulation (unincorporated enterprises); with no complete set of accounts and produce some market output. This definition excludes all agricultural activities and all production for self consumption or for non market purposes.

In the Indian context, the informal sector is a part of the unorganized sector, which also includes within its ambit enterprises solely engaged in non-market production, i.e. production for own final consumption and own gross fixed capital formation and all agricultural activities. There is a need to articulate a vision for a scaled, national, financial infrastructure aimed at delivering a complete suite of financial services to the unorganized sector. Also there is a need to identify the gaps and suggest strategies for creation of an "Enabling Environment" through investments in facilitative infrastructure for the growth of the sector. The key arguments for creation of a facilitative infrastructure are based on the following premises:

1. Micro enterprises boost the local economy, as they are considered to be labour intensive, accounting for approximately 92 per cent of the total working population of the country.

2. It creates positive distribution of wealth because of the highly dispersed presence of the sector throughout the country.

3. Existence of a vibrant financial infrastructure tuned to the unorganized sector, could catalyze its growth.

Financial Needs of the Poor: Every household, irrespective of its rural/urban status or its economic status has a set of consumption and investment needs. Consumption is any spending, e.g. for food, for transport, for education etc. Investment is any spending that creates future income, e.g., land, purchase of assets etc. Many experts hold that among the poor, there is no difference between consumption and investment. The needs for funds that typically arise in a poor family are as below:

1. Life cycle needs: Family events like marriage, death, birth, festivals etc.

2. Emergency needs: Medical emergencies, natural calamities, thefts, accidents etc.

3. Investment needs: Asset purchase, starting micro and small businesses.

All the above listed needs and occasions call for access to funds, which could be often substantial. The ways in which the poor try to meet their needs are:

1. Use of savings

2. Borrowing

3. Sale/Mortgage of assets like land, livestock, valuables etc.

Banking Services to the poor: India has one of the largest networks of bank branches in the world, but the hundreds of millions of poor in the country are largely out of it. Banks were nationalized three decades ago with the hope that their services would reach the poor. With 52,000 commercial bank branches, 14,522 branches of regional rural banks and 100,000 cooperative bank branches, the country is teeming with institutions that should be able to meet the credit needs of the people. Menon (2005) has pointed out that 75 million households in India depend on moneylenders to meet financial needs; almost 90 per cent of people in rural India have no access to insurance; 50 million households are landless and need small credit to start some economic activity. And even families earning Rs.4000-5000 a month in urban areas spend huge portions of their earnings to service debt. But out of necessity and enterprise, those locked out of the banking world have found a way out called micro credit - the extension of small loans to individuals who are too poor to qualify for traditional bank loans, as they have no assets to be offered as guarantee. In India, micro credit has worked largely through self-help groups. Predominated by women, these are formed with simple rules save, accumulate and give loans to each other. Globally, it is slowly proving one of the most effective strategies to neutralise poverty. 
Micro credit lending institutions are currently estimated to reach some two million households in India. Despite the emergence of a number of dynamic private sector banks and entry by a large number of foreign banks, the biggest banks in India are all in the public sector, i.e., they are corporate banks with the government as the controlling share-holder. The public sector banks collect over $77 \%$ of deposits and comprise over $90 \%$ of all branches. While banks in India occasionally provide longer-term loans, financing fixed capital is primarily the responsibility of specialized long-term lending institutions such as the Industrial Finance Corporation of India. Banks typically provide short-term working capital to firms. These loans are given as a credit line with a pre-specified limit and an interest rate that is set a few percentage points above the prime rate. The spread between the interest rate and the prime rate is fixed in advance based on the firm's credit rating and other characteristics, but cannot be more than $4 \%$. Credit lines in India charge interest only on the part that is used and, given that the interest rate is pre-specified, many borrowers want as large a credit line as they can get.

All banks (public and private) are required to lend at least $40 \%$ of their net credit to the "priority sector", which includes agriculture, agricultural processing, transport industry, and small enterprises. If the banks fail to meet the target of $40 \%$ lending to the above mention priority sector areas, they are required to lend money to specific agencies as indicated by the Government of India at very low rates of interest. There is a growing and worldwide appreciation that the Micro, Small and Medium Enterprises (MSMEs) play a catalytic role in the development process of most economies. This position gets reflected in the form of their increasing number and rising proportion in the overall product manufacturing, exports, manpower employment, technical innovations and promotion of entrepreneurial skills. In India, the MSME sector is the second largest manpower employer, after agriculture. This sector contributes one third of India's national exports and also $40 \%$ towards the output in the manufacturing sector. Table 1 below quantifies the performance of small scale industries in India from 1973-74 to 2007-2008. The production data at current prices, the employment from the sector and the exports of the sector in INR as well as USD are indicative of the contribution made by MSMEs to the Indian economy. The importance of Micro, Small and Medium enterprises (MSMEs) for its contribution in the Indian economy growth is a matter of record and needs no further elaboration. However with the changing focus from economic growth to inclusive growth, MSME sector's role in the socio economic development of India needs to be understood, explored and facilitated.

\section{In the Table:}

P-provisional/projected

\section{Note:}

1. The estimates of employment for the period 2002-03 to 2005-06 have been revised. The Third All-India Census surveyed the units registered up to 2000-01, while its reference period was 2001-02. Adjustments have been made in the estimates using the number of units registered with State/UTs Government after 31.3.2001.

2. The estimates of production for 2006-07 have been calculated from the previous year's growth by assuming that a 13 percent growth would be achieved in 2006-07.

* Since 2001-02, production figures are at 2001-02 prices.

Within the MSME sector, the micro and the small sectors serve as a green field for nurturing of entrepreneurial talent and helping the units to grow in to medium and large size. The promotion of MSMEs, therefore, becomes a major area for policy focus, both in developed as well as developing countries. 
Table1: Performance of Small Scale Industries in India 1979-80 to 2006-07

\begin{tabular}{|c|c|c|c|c|c|c|c|}
\hline \multirow[t]{2}{*}{ Year } & \multirow[t]{2}{*}{$\begin{array}{c}\text { Units } \\
\text { (Million } \\
\text { Nos) }\end{array}$} & \multicolumn{2}{|c|}{$\begin{array}{l}\text { Production } \\
\text { (Rs in crore) }\end{array}$} & \multirow[t]{2}{*}{$\begin{array}{c}\text { Employment } \\
\text { in } \\
\text { mill nos. }\end{array}$} & \multirow{2}{*}{$\begin{array}{c}\text { Prod. Per } \\
\text { Employee } \\
\text { ( Rs. '000) } \\
\text { At } \\
\text { 1993-94 } \\
\text { prices } \\
\end{array}$} & \multicolumn{2}{|c|}{ SSI Exports } \\
\hline & & $\begin{array}{l}\text { At 1993-94 } \\
\text { Prices }\end{array}$ & $\begin{array}{l}\text { At Current } \\
\text { Prices }\end{array}$ & & & $\begin{array}{l}\text { Rs. } \\
\text { Crore }\end{array}$ & $\begin{array}{c}\text { US \$ } \\
\text { Millio } \\
\text { n }\end{array}$ \\
\hline $1979-80$ & 0.81 & 66400 & 21600 & 6.7 & 99 & 1200 & 1518 \\
\hline $1980-81$ & 0.87 & 72200 & 28100 & 7.1 & 102 & 1600 & 2078 \\
\hline 1981-82 & 0.96 & 78300 & 32600 & 7.5 & 104 & 2100 & 2309 \\
\hline $1982-83$ & 1.06 & 84700 & 35000 & 7.9 & 107 & 2000 & 2116 \\
\hline $1983-84$ & 1.16 & 93500 & 41600 & 8.42 & 111 & 2200 & 2093 \\
\hline 1984-85 & 1.24 & 104600 & 50500 & 9 & 116 & 2500 & 2137 \\
\hline $1985-86$ & 1.35 & 118100 & 61200 & 9.6 & 123 & 2800 & 2263 \\
\hline 1986-87 & 1.46 & 133600 & 72300 & 10.14 & 132 & 3600 & 2851 \\
\hline $1987-88$ & 1.58 & 150500 & 87300 & 10.7 & 141 & 4400 & 3372 \\
\hline $1988-89$ & 1.71 & 169900 & 106400 & 11.3 & 150 & 5500 & 3790 \\
\hline $1989-90$ & 1.82 & 189900 & 132300 & 11.96 & 159 & 7600 & 4579 \\
\hline $1990-91$ & 6.79 & 84728 & 78802 & 15.83 & 54 & 9664 & 5386 \\
\hline 1991-92 & 7.06 & 87355 & 80615 & 16.6 & 53 & 13883 & 5632 \\
\hline 1992-93 & 7.35 & 92246 & 84413 & 17.48 & 53 & 17784 & 6140 \\
\hline $1993-94$ & 7.65 & 98796 & 98796 & 18.26 & 54 & 25307 & 8068 \\
\hline 1994-95 & 7.96 & 108774 & 122154 & 19.14 & 57 & 29068 & 9258 \\
\hline $1995-96$ & 8.28 & 121175 & 147712 & 19.79 & 61 & 36470 & 10903 \\
\hline 1996-97 & 8.62 & 134892 & 167805 & 20.59 & 66 & 39248 & 11056 \\
\hline 1997-98 & 8.97 & 146263 & 187217 & 21.32 & 69 & 44442 & 11958 \\
\hline 1998-99 & 9.34 & 157525 & 210454 & 22.06 & 71 & 48979 & 11642 \\
\hline 1999-00 & 9.72 & 170379 & 233760 & 22.91 & 74 & 54200 & 12508 \\
\hline $2000-01$ & 10.11 & 184401 & 261297 & 24.09 & 77 & 69797 & 15278 \\
\hline 2001-02 & 10.52 & $282270^{*}$ & 282270 & 25.23 & $112^{*}$ & 71244 & 14938 \\
\hline $2002-03$ & 10.95 & 306771 & 314850 & 26.37 & 116 & 86013 & 17773 \\
\hline 2003-04 & 11.4 & 336344 & 364547 & 27.53 & 122 & 97644 & 21249 \\
\hline 2004-05 & 11.86 & 372938 & 429796 & 28.76 & 130 & 124417 & 27690 \\
\hline 2005-06 & 12.34 & 418884 & 497842 & 29.99 & 140 & 150242 & 33935 \\
\hline 2006-07(P) & 12.84 & 471663 & 585112 & 31.25 & 151 & - & - \\
\hline 2006-07(P) & 13.84 & 471664 & 585113 & 32.25 & 152 & - & - \\
\hline
\end{tabular}

Source: Reserve Bank of India. \& Ministry of Commerce and Industry, Govt. of India.

\section{About MSMEs}

MSMEs play a vital role in the socio economic uplift of the society and are contributors to the areas like employment generation, balanced regional growth. The areas of contribution have been discussed below:

\section{Significance of MSMEs}

MSMEs contribute to the socio economic development of the country, by way of: 
Wide spread reach: There are around 12.34 million MSMEs; including 1.9 million registered one which are spread out across the length and breadth of India. They may be touching the lives of 123.4 million directly or indirectly which is roughly $10 \%$ of India's population.

Major share in GDP: MSMEs combined output is roughly 7\% of country's Gross Domestic Production (GDP).

Big employment generator: MSME sector is the second largest manpower employer in the country next only to agriculture sector. It provides employment to more than 20 million people which are roughly $2 \%$ of country's population. From a social angle, it helps in solving the unemployment and under-employment problem in the society.

Facilitates balanced regional development: Dispersion of MSMEs in all parts of the country helps in removing regional imbalances by promoting decentralized development of industries. MSMEs can be found every where, which may be rural, urban, coastal, desert, mountains, forest, backward/ forward areas. This decentralized concept also helps in reducing the other problems like pollution, congestion, housing, sanitations etc.

Helps in equitable distribution of wealth/ income: When the entrepreneurial talent is allowed to grow in different regions and areas, the income is also distributed instead of being concentrated in the hands of few. This help in solving a big social issue of bridging the gap between rich and poor.

Act as nursery for entrepreneurship: MSMEs provide a natural habitat for entrepreneurs. Through this platform, the latent/ raw talent available locally can hone their skills and talents, to experiments, to innovate and transform their ideas into goods and services needed by the society.

The areas of contribution of MSEME and their interaction with different stakeholders have been depicted in Figure 2 below. The figure is also representative of the interplay of relations with each of the stakeholders.

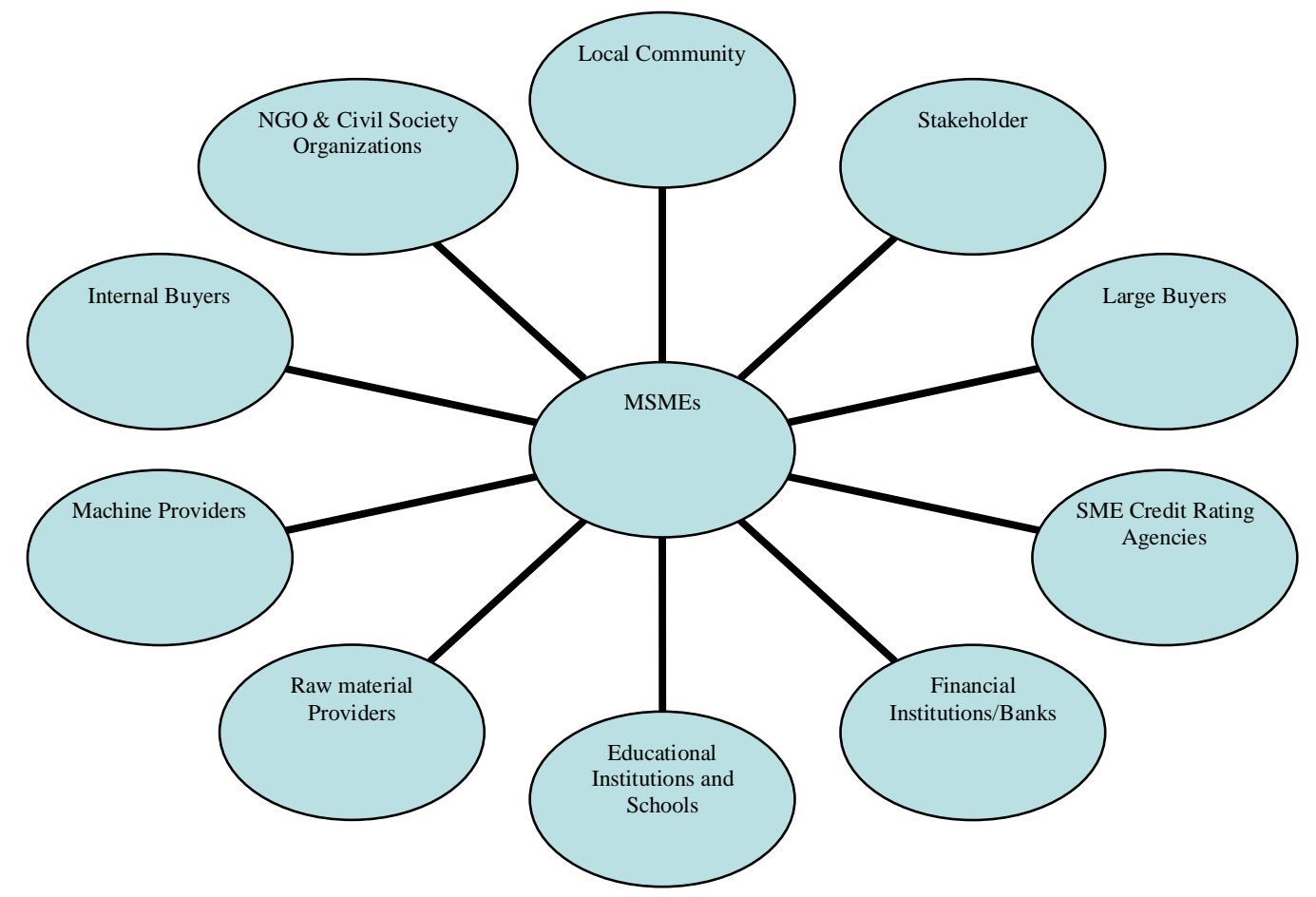

Figure 2: MSMEs-Interaction with different stakeholders 


\section{Evolution of the MSME - the India Story}

Definition of SME - A relative phenomena: There is no universal definition of small and medium enterprises. In some countries, there are certain objective standards, which classify the units as Micro, Small or Medium Enterprises depending on the number of employees. In some other countries, annual turnover of the company determines the size of an enterprise. The concept of size is also a relative phenomenon with reference to the local economies, since a large company in a small country could possibly be considered as a small company in a larger country.

Contribution of Indian SSIs: Small Scale Industries (SSIs) have a significant role to play in the socioeconomic up liftment of developing countries like India. The SSIs occupy a unique position in the Indian economy for its contribution towards value-addition, employment generation, expansion of entrepreneurial base, and also for the diversification of the industrial sector. After independence, the Indian government recognized the importance of developing SSIs and incorporated the same in its industrial policy. That has been the primary reason for the growth rate in the employment in SSI over the years. The Table 2 below shows the growth rate in employment in SSIs from 2002 to 2006.

Table 2: Employment Growth rates in SSIs in India from2002-03 to 2005-06

Estimated Employment Growth Rates in SSIs in India (2002-2003 to 2005-2006)

(Employment-Lakh Persons)

\begin{tabular}{ccc}
\hline Year & \multicolumn{2}{c}{ Estimated Employed in SSI } \\
& Employment & Growth Rate \\
$2002-03$ & 260.21 & $4.36 \%$ \\
$2003-04$ & 271.42 & $4.31 \%$ \\
$2004-05$ & 282.57 & $4.11 \%$ \\
$2005-06$ & 294.91 & - \\
\hline
\end{tabular}

Source: Lok Sabha starred question No.229, dated 08.08.2006

Over the years, the SSI sector in India has continued to remain an important sector of the economy with its noteworthy contribution to the gross domestic product, industrial production, employment generation and exports. India initiated the economic reforms in 1991 with the objective of faster economic growth. As per the Third All India Census of SSIs (2001-02), there were 10.52 million SSI units in the country, of which 1.37 are registered and 9.15 unregistered units. For the year ended March 2004, the said number increased to 11.52 million, providing employment to 27.40 million persons and contributing an output of over Rs.3, 480 billion in FY2004. The Tenth Five Year Plan for the Indian economy has set a target of 8 percent growth per annum in GDP and to bring down the poverty ratio to 11 percent over the next decade. The Plan has also noted that achieving and sustaining such ambitious growth targets would require adequate attention to small and medium enterprises which have great potential to offer wage employment. In order to pursue the growth with employment agenda, heavy reliance is placed on the SME sector.

Bodla and Verma (2008), reveal that the growth in the share of exports of SSIs in total exports of India was higher in pre-liberalization period than the post-liberalization period. Compound Annual Growth Rate (CAGR), with reference to the number of units, employment level, production, and value of plant and machinery in SSIs were also comparatively higher in the pre-liberalization period. The percentage share of SSI sector in total bank credit and in total outlay of various five year plans has also declined significantly. Moreover, this sector is growing at a rate half of the total industrial growth rate. The inference was that the SSI sector could not grow to the desired level due to intense competition from large and medium sized domestic and multinational companies. The objective of the policymakers as well as small industry associations was to enable the sector to be vibrant, competitive and to focus on R\&D not only to improve the overall quality, but also to deliver a superior product in the market. 


\section{The Small Scale Industries (SSI) Sector in India}

The promotion of the small-scale sector in India has been an important thrust of industrial policy since independence though the focus of concern changed with the priorities of each five year plan. The Industrial Policy Resolutions which have been framed since 1948 have set out the guidelines for the country's industrial development with different degrees of emphasis on the main objectives. The Industries Development and Regulation Act of 1951 provided the basic framework for the post-independence industrialization strategy. The model for industrialization in the 1950s was based on capital-intensive heavy industries; this meant that the employment generation was the priority for the small scale units. As the process of economic development led to changing priorities, the policy focus shifted towards corrective measures to counter regional imbalances (1977), promote ancillarisation (1980), encourage exports and dispersal in rural areas (1990) and then to promote Small, Tiny and Village Industries (1991). During all these years the definition of SSIs in India kept changing based on the changing ecosystem and the progress of the economy as compiled in the Table 3 below.

Table 3: Official definition of SSIs in India from 1950 to 2001.

\begin{tabular}{lcc}
\hline & \multicolumn{2}{c}{ Official Definition of SSIs in India } \\
Year & (1950, 1960, 1966, 1975, 1980, 1985, 1991, 1997 to 1999 \& 2001) \\
Investment Limits & Additional Conditions \\
\hline 1950 & Upto Rs. 5 Lakh in fixed assets & $\begin{array}{c}\text { Less than } 50 / 100 \text { persons with or } \\
\text { without power }\end{array}$ \\
& & No Condition \\
1960 & Upto Rs. 5 Lakh in fixed assets & No Condition \\
1966 & Upto Rs. 7.5 Lakh in Plant \& Machinery & No Condition \\
1975 & Upto Rs. 10 Lakh in Plant \& Machinery & Additional Conditions \\
Year & Investment Limits & No Condition \\
1980 & Upto Rs. 20 Lakh in Plant \& Machinery & No Condition \\
1985 & Upto Rs. 35 Lakh in Plant \& Machinery & No Condition \\
1991 & Upto Rs. 60 Lakh in Plant \& Machinery & No Condition \\
1997 & Upto Rs. 300 Lakh in Plant \& Machinery & No Condition \\
1998 & Upto Rs. 1 Crore in Plant \& Machinery & No Condition \\
1999 & Upto Rs. 100 Lakhs in Plant \& Machinery* & No Condition \\
2001 & Upto Rs. 100 lakhs in Plant \& Machinery* & (10)
\end{tabular}

Source: Compiled from the statistics released by Small Scale Industries in India, Office the Development Commissioner, Ministry of SSI, Govt. of India 2002.

\section{In the Table}

\section{Note}

1. With effect from October 2001, the investment ceiling in Plant \& Machinery in respect of 41 items covering two broad groups of Hosiery \& Hand Tools has been enhanced to Rs. 500 Lakhs.

2. Year: Period of fiscal year in India is April to March, e.g. year shown as 1990-91 relates to April 1990 to March 1991.

3. Units: 1 Lakh (or Lac) $=100000,1$ Crore (or Cr.) $=10000000$.

The organizational structure for SSIs was set up in the 1950s with the establishment of a Small Scale Industries Board in 1954. Other important institutions at the national level were the Department of Small Scale Industries and Agricultural \& Rural Industries and the Small Industries Development Organisation (SIDO) which was under the development Commissioner, Small Scale Industries. At the State level, the Commissioner/ Directorate of Industries were the main institutional authority for SSIs. This structure has 
remained, though several other institutions have come into being in the 1970s and 1980s, particularly at the State level.

During the last forty years, several committees have been constituted by the Government of India to examine the functioning of SSIs with a view to promoting their growth and efficiency within the context of the main objectives of the national economic plans. The Karve Committee Report was one of the earliest attempts to create a protective environment for the growth of small industries in India (Government of India 2007). Since then, policies targeted for the SSI sector have aimed at fostering its growth through positive policy interventions in the areas of finance, technology, infrastructure and extension services, amongst several other requirements of the sector. Supportive policies through the 1960s, 70s and 80s took the form of reservation of products exclusively for the SSI sector (836 products were reserved exclusively for SSIs). To facilitate the increased credit flow to the SSI sector, a policy of priority sector lending through nationalized banks has been followed, though this has not been adequate for the growth requirements of the sector. Since the 1980s and, more particularly, in the 1990s, there have been marked changes in the policy climate across the globe towards free markets and reduced government intervention. The global economy is characterized by greater integration, a more liberalized international trade regime following the set up of the World Trade Organization (WTO). We have witnessed a rapid pace of technological change, especially in growth areas such as information and knowledge-based industries. India's economic policies are in the process of being restructured, through the second generation reforms, to adjust to the emerging challenges. The main emphasis of future policy will be to promote the growth of this dynamic sector through focused, sustained and wide-ranging interventions, as the SSI sector has so far been insulated to a large extent from pressures of competition both domestically and internationally.

\section{Government policies and support measures for MSMEs: Brief History}

The evolution of the policy framework and support measures of the government can be broadly grouped into following three periods:

1948-1991 - In the policy resolutions from 1948 to 1991, recognition was given to the tiny and small enterprises. They were termed as an effective tool to expand employment opportunities, help ensure equitable distribution of the national income and facilitate effective mobilization of private sector resources of capital and skill. The Small Industries Development Organization (SIDO) was setup in 1954 as an apex body for sustained and organized growth of small enterprises. This is now known as the Micro, Small and Medium Enterprises Development Organization. In 1956, the National Small Industries Corporation, The Khadi and Village Industries Commission and the Coir Board were also setup. The era provided the supportive measures that were required to nurture the small enterprises in the form of reservation of items for their exclusive manufacture, access to bank credit on priority through the priority sector lending program of commercial banks, excise exemption, reservation under the government purchase program. The Small Industries Service Institute (SISI) now known as MSME Development Institute was setup all over India to train youth in skills, and the tool rooms were established with German and Danish assistance for providing technical services essential to small enterprises for skilled training. At the state level, District Industry Centers (DIC) are setup all over the country.

1991-1999 - The new policy for small, tiny and village enterprises of August 1991 laid the framework for government support in the context of liberalization which sought to replace the protection with competitiveness to infuse more vitality and growth to small enterprises in the face of foreign competition and open market. Supportive measures concentrated on improving infrastructure, technology and quality. Testing centers and new tool rooms were setup. The Small Industry Development Bank of India (SIDBI) and a technology development modernization fund were created to accelerate technical and financial services to the small scale sector.

1999 onwards - The ministry of MSME (earlier known as ministry of SSI and Agro and Rural Industries) came into being from 1999 to provide focused attention to the development and promotion of the sector. The new policy package announced in Aug 2000 sought to address the problems of credit, infrastructure, technology and marketing. A credit linked capital subsidy scheme was launched to encourage technology up gradation in 
the MSE sector and credit guarantee scheme was started to provide collateral free loans to micro and small entrepreneurs, particularly the first generation entrepreneurs. The exemption limit for relief from payment of Central Excise duty was raised to Rs 1crore ( $\$ 0.25$ million) and a Market Development Assistance Scheme for MSEs was introduced. At the same time, consultations were held with stakeholders and the list of products reserved for production in the MSE sector was gradually reduced each year. In 2006, the long awaited enactment for this sector finally became a reality with the passage of the Micro, Small and Medium Enterprises Act. In March 2007, a third package for the promotion of Micro and Small Enterprises was announced which comprises the proposals/schemes having direct impact on the promotion and development of the micro and small enterprises, particularly in view of the fast changing economic environment..

\section{Present Policy Framework and Focus Areas}

\section{Micro, Small and Medium Enterprises Development Act, 2006}

The Micro, Small and Medium Enterprises Development (MSMED) Act, 2006 seeks to facilitate the development of these enterprises as also enhance their competitiveness. It provides the first ever legal framework for recognition of the concept of 'enterprise' which comprises both manufacturing and service entities. It defines medium enterprises for the first time and seeks to integrate the three tiers of these enterprises namely micro, small and medium. The act also provides for a statutory consultative mechanism at the national level with balanced representation of all sections of stakeholders, particularly the three classes of enterprises; and with a wide range of advisory functions. Establishment of specific funds for the promotion, development and enhancing competitiveness of these enterprises, notification of schemes/programmes for this purpose, progressive credit policies and practices, preference in Government procurements to products and services of the micro and small enterprises, more effective mechanisms for mitigating the problems of delayed payments to micro and small enterprises and assurance of a scheme for easing the closure of business by these enterprises are some of the other features of the Act.

The Ministry of MSME has also taken a view, in the light of the liberalized provisions of the MSMED Act 2006, to do away with the restrictive $24 \%$ ceiling prescribed for equity holding by industrial undertakings, whether domestic or foreign, in the erstwhile Small Scale Industries(now MSEs). This coupled with an expected legislation on Limited Liability Partnerships (introduced in the Parliament by the Ministry of Corporate Affairs) should pave the way for greater corporatisation of the Small and Medium Enterprises-thereby enhancing their access to equity and other funds from the market of these products in keeping with the global standards. The Ministry of Micro, Small and Medium Enterprises has drawn up a road map and has been holding detailed consultations with stakeholders to generate consensus on further trimming this list.

\section{Definition of MSMEs in India:}

As per the MSME Act 2006 the Enterprises are broadly classified into 2 categories;

i. Manufacturing

ii. Those engaged in providing and rendering of services

Both categories of enterprises have been further classified into micro, small, medium and large enterprises based on their investment in plant and machinery (for manufacturing enterprises) or on equipments (in case of enterprises providing or rendering services). The present ceiling on investments to be classified as micro, small or medium enterprises is as under:

Table 4: Classification of MSMEs based on the MSMED Act 2006

\begin{tabular}{lll}
\hline \multirow{2}{*}{ Classification } & \multicolumn{2}{c}{ Investment ceiling for Plant, } \\
& Manufacturing enterprises & \multicolumn{1}{c}{ Service enterprises } \\
\hline Micro & Upto USD 62500 & Upto USD 25000 \\
\multirow{2}{*}{ Small } & Between USD 60000 to USD 1.25 & Between USD 25000 and USD \\
& million & 0.5 million \\
\multirow{2}{*}{ Medium } & Between USD 1.25 million \& USD & Between USD 0.5 million and \\
& 2.5 million & USD 1.25 million \\
\hline
\end{tabular}


Table 5: Definitions before October 2006

\begin{tabular}{llll}
\hline \multicolumn{1}{c}{ Classification } & \multicolumn{3}{c}{$\begin{array}{c}\text { Investment ceiling for Plant, Machinery or Fixed Assets* } \\
\text { Manufacturing enterprises }\end{array}$} \\
\hline Micro & $\begin{array}{l}\text { Upto USD 62500 } \\
\text { Between USD } 60000 \text { to }\end{array}$ USD 0.25 & Upto USD 25000 \\
Small & $\begin{array}{l}\text { million } \\
\text { Not defined }\end{array}$ & & Not defined \\
Medium & n & & \\
\hline
\end{tabular}

Excluding Land and Building \$1=Rs 40 (Oct 2007)

Table 6: Micro, Small and Medium Enterprises (MSME) Sector Profile

\begin{tabular}{lcc} 
& Old Definition & New Definition \\
\hline No. of Micro and Small Enterprises & 12.8 million & 13.0 million* \\
Employment & 31.0 million & 41.0 million \\
Production (at current prices) & USD 140 billion & NA \\
Exports (USD) & USD 33 billion & NA \\
Share in GDP & $6 \%$ & $8-9 \%^{*}$ \\
Share in manufacturing output & $39 \%$ & $45 \%^{*}$ \\
Share in exports & $33 \%$ & $40 \%^{*}$ \\
\hline
\end{tabular}

The statistics relating to Micro and Small Enterprise are based on $3^{\text {rd }}$ All India Census conducted during 200102 when the old definition was invoked. The statistics relating new definition are based on unofficial sources and the final picture will emerge from the $4^{\text {th }}$ All India Census to be conducted during 2007-09.

Table 7: Annual Flow of Credit 2006-07

\begin{tabular}{lll}
\hline Indicator & MSEs(Former SSIs) & MSME Sector \\
\hline Public Sector Banks & USD 5.4 billion & USD 9.4 billion \\
Other banks & USD 2.4 billion & USD 3.5 billion \\
Other emerging sources & NIL & USD 3.0 billion \\
Total & USD 7.8 billion & USD 12.0 billion \\
\hline
\end{tabular}

Exchange rate used for conversion Rs. $40=1$ USD

\section{Medium Enterprises: Profile}

1. The medium enterprises has been defined for the first time under the Micro, Small and Medium Enterprises Development (MSMED) Act 2006 which came into force on 2nd October 2006.

2. Hence, no firm statistics is available in respect of medium enterprises presently.

3. Statistics relating to the medium enterprises would be captured in the $4^{\text {th }}$ All India Census.

4. Informal sources suggest the number of medium enterprises in India to be around ten to fifteen thousand. Further it is estimated that they contribute about $2 \%$ to GDP over $5 \%$ to manufacturing output and $10 \%$ to national exports.

\section{Growth and Progress in the MSME sector}

Micro, Small and Medium Enterprises (MSMEs) are an integral and important part of Indian industry and economy. During the pre-Independence era, no emphasis was given to organized industrialization of the county. The historical background of India, the skill and craftsmanship present, and the availability of natural resources enabled individual endeavors with low capital investment possible. These endeavors were mostly in the form of micro industries run manually. After Independence in 1947, the foremost task for the government was to achieve rapid industrialization of the country with in the overall framework of a welfare state.

The guiding principles for the welfare state enshrined in the Derivative Principle of State Policy in the Constitution of India, entrusted upon the states to strive to minimize income inequalities and general disparities, and also to promote micro industries in the rural area. Since Independence, there has been an all 
around development of MSMEs in India. The performance and contribution to the growth of industrial economy of India has been quite remarkable. The allocation of funds for the various schemes and programs under the MSME growth plan scheme shows that the government has been serious and therefore aims at a high growth rate. The growth rate of MSME sector is at 12 percent per annum in terms of production, and it has been faster than that of large scale since 1973.

\section{Implications}

The present rate of growth in MSME sector is 12 percent. The government's focus in recent years has been skill development for the teeming millions to achieve all-round growth. The production of MSMEs have increased from Rs. 13,600 crore in 1973-74 to more than Rs. 5,78,000 crore in 1999-2000. It is estimated that they contributed almost 50 percent of the gross value of output in the manufacturing sector.

The number of registered and unregistered MSMEs which stood at 16,000 units in 1950 increased to 5.30 lakh in 1981-82 and to 32.25 lakh in 1999-2000 and now it reached to 118.59 lakh in 2004-05. At present MSMEs in India contributes more than 80 percent of the total number of industrial enterprises. The MSME sector employed 282.57 lakh persons in 2004-05 compared to 90 lakh and 178.5 lakh persons in 1984-85 and 1988-89 respectively. This represents about 60 percent of the total industrial employment. Employment in MSME industries is next only to that of agriculture sector. Export from this sector increased from Rs. 852 crores in 1973-74 to Rs. 4535 crores in 1988-89 and further to around more than Rs. 54,000 crores in 19992000. It is estimated that this sector contributes over 50 percent of the manufacturing export and 34 percent of the total export in the present year. MSME sector produce a wide range of producer and consumer goods items needed by the economy. They include simple and sophisticated engineering products, electrical, electronics, chemicals, plastic, steel, cement, textile, paper, matches, and ready made garments and so on. Ancillary units contribute greatly to these numbers and cater to the requirements of the medium and large industrial units for materials, components, consumables and so on.

The traditional village and cottage industry which are generally clubbed with modern small scale industries provide vital means of living to artisans, sustain the vitality and viability of countless number of villages and towns, enrich the quality of life in society by providing fine handicrafts and pieces of art and project the heritage of India. A large number of MSMEs are engaged in the manufacturing of the consumer goods of mass consumption, thereby making them available in plenty which serves as a non-inflationary force. The employment generation capacity per unit of capital of MSME was found to be at least eight times higher of large industries while the output generating capacity per unit of capital was three times larger than that of large industries. The encouragement of MSMEs with their higher out-put-capital ratio and employmentcapital ratio has become a stabilizing force in the Indian economy. Of all the elements that go into a business, credit is perhaps the most crucial. The best of plans can come to naught if adequate finance is not available at the right time. MSMEs need credit support not only for running the enterprise \& operational requirements but also for diversification, modernization, up gradation of facilities, capacity expansion, etc. In respect of MSMEs, the problem of credit becomes all the more critical whenever any episodic event occurs such as a large order, rejection of consignment, inordinate delay in payment, etc. In general, MSMEs operate on tight budgets, often financed through owner's own contribution, loans from friends and relatives and some bank credit. Also, the information asymmetries associated with lending to small scale borrowers have restricted the flow of finance to the micro enterprises 


\section{References:}

Government of India (2002). India Vision 202. Planning Commission, India.

Government of India (2007). Industrial Policy and Promotion. Karve Report, 10(3), Ministry of Commerce and Industry.

Menon, R. (2005). Film on micro credit, to their credit .... Produced by The Energy and Resources Institute, Financed by The Swiss Agency for Development and Corporation.

Rahman, A. (1999). Micro-credit Initiatives for Equitable and Sustainable Development: Who Pays? World Development, 27(1): 67-82.

Ruchismita, R and Gupta, P (2005). An Approach paper for the Delivery of Comprehensive Financial Services to the Informal and Unorganized Sector. Source: ICICISocialinitiatives.org.

Bodla, B. S. and Verma, S. R. (2008). An analysis of the performance of SSIs in the era of globalization. The Icfai Journal of Managerial Economics, 6(3): 40-53.

Dodge, H. R. and Robbins, J. E. (1992). An empirical investigation of the organizational life cycle model for small business development and survival. Journal of Small Business Management, 30(1): 27-37.

Shaw, E. (1999). A guide to the qualitative research process: evidence from a small firm study. Qualitative Market Research: An International Journal, 2: 59-70. 